\section{Bioinspired mathematical model to establish complex patterns for parametric facades \\ Natália Queiroz ${ }^{(1)}$ and Fernando Oscar \\ Ruttkay Pereira ${ }^{(2)}$}

\begin{abstract}
The facade is the skin that filters and promotes the interaction between the interior and exterior of the building. During its conception process, one must understand environmental patterns, observe the incident climate, and propose solutions that consider the use of the building and take advantage of the climate's opportunities, filtering advantages and disadvantages. Facades are composed of opaque and transparent elements, closed and open, and the openings are the elements that promote the greatest connection between the external and internal environments. Recent design explorations consider parametric modeling and digital fabrication as strategies to establish and manufacture complex facade solutions. Nevertheless, these solutions often disregard their selective filtering function, thus the solutions are established frequently through aesthetic requirements. The complexity of modeling the building skin solution associated with performance requirements hinders an approach compatible with bioclimatology, efficiency, and biomimetic requirements, as it increases the mathematical problem complexity for optimization processes associated with environmental characteristics. This paper presents a mathematical model inspired by nature and its principles to simplify form-finding processes of complex solutions in responsive facades. The result features a flexible simplified algorithm capable of generating patterns for any kind of shading devices and/or opening solution, in order to facilitate the modeling and optimization processes of facade solutions. The generated algorithm is applied using Python script, Grasshopper and Rhinoceros 3D.
\end{abstract}

Keywords: Façade - Parametric modeling - Bio-inspiration - Algorithm - Pattern - Facade design - Building skin - Responsive design - Grasshopper - Python.

[Abstracts in spanish and portuguese at pages 221-222]

(1) Natália Queiroz. Architect, Master in product design at Federal University of Pernambuco. PhD student in Architecture and urbanism at Federal University of Santa Catarina. She has experience in research in environmental comfort, computational simulation, energy efficiency, sustainability and biomimetic applied to building design. Currently, researches performance-based design processes, considering the use of parametric modeling integrated to data, performance requirements and optimization. She has worked on a number of research projects, scientific publications, and designs. She also has awards in the area of research and design. Among the awards in his career stand out the award 
"Museu da Casa Brasileira" (MCB) in 2016 (the most traditional prize in product design in Brazil).nataliaqueiroz@labcon.ufsc.br

(2) Fernando Oscar Ruttkay Pereira. Civil engineering. Ph.D. at School of Architectural Studies, University of Sheffield, England. Post doctorate at School of Civil and Building Engineering, University of Loughborough. England. Professor at Department of Architecture and Urbanism in the Federal University of Santa Catarina. He founded the first Environmental Comfort Laboratory in Brazil (1986) at the Federal University of Santa Catarina. Today a reference in the country in research about environmental comfort and Building performance.

\section{Introduction}

According to Kolarevic [1], parametric design designates the use of parameters in the design process. Considering that any design process is based on parameters, the term can be redundant. The term designates the use of associative digital models consisting of variable parameters and constraints. Parameters can be numerical based on geometry, or process automation, and also performance-based, when associated with data analysis and analysis cycles [2-4].

The biomimetic design method is related to the performance-based design process since every natural solution is associated with its intrinsic performance, which is related to the formal characteristics of the solution [5]. Although still far from the efficiency of nature, the strategy of integrating the analytical steps with the generation of form through parametric modeling processes is an option to reproduce a principle that resembles the form and pattern definitions present in nature [4-6].

Considering buildings, the facade is analog to the skin in most animals, in the sense that it filters and promotes the interaction between the interior and exterior of the building [7]. Thus, it could respond to environmental pressure, weather and time, that impact human activity within the building. Al Horr et al. [8] addresses eight physical aspects related to the building skin design, with varying relevance, according to building users, are they:

1. Indoor air quality and ventilation

2. Light and daylighting

3. Thermal comfort

4. Noise and acoustics

5. Spatial arrangement

6. Biophilia and views

7. Look and feel

8. Location and amenities. 
Facades are no longer considered as simple physical barriers between the interior conditions and exterior of a building, but rather as a complex system that determines spatially involved environments. During its conception process, one must understand environmental patterns, observe the incident climate, and propose solutions that consider the use of the building and take advantage of the climate benefits, filtering advantages and disadvantages [7-9]. In this perspective, building skins have the potential for promoting significant reductions in energy use, integration of clean construction techniques, good quality daylight filtering, heat protection, etc. In other words, they are being developed and implemented to maximize environmental gains such as improving air and water quality, reusing and recycling materials, managing ingenious materials and reducing carbon emissions, among others [7-9].

The facade is composed of opaque and transparent elements, closed and open, and the openings are the elements that promote the greatest connection between the external and internal environment [9]. Recent explorations consider parametric modeling and digital manufacturing as strategies to establish and manufacture complex facade solutions. The design based on facade commitment often involves aspects of permeability to light and heat, air and therefore involves a lot of data, because of that the modeling process to establish a sensible solution can be difficult to formulate and understand [10].

An opening can be understood as a building pore. It is the element of the facade that establishes the most direct communication between interior and exterior. Each opening has individual characteristics associated with the internal and external environment. To exemplify, Reinhart and Loverso [11] discuss the influence of urban configuration on daylight performance in indoor spaces, and have established a parametric solution for the openings to meet the minimum performance of daylight in the internal spaces. The solution shows each opening with size variations, and the urban configuration could even make it impossible to comply with minimal daylighting requirements on the first floors. Other example, a radiation analysis can also exemplify that aspects of solar geometry and the surroundings generate differentiated impacts along the facades (See Figure 1).

When considering an optimization process, it can be concluded that each window would have a unique response to address performance aspects, depending on its position on the facade and relation to the urban context. Therefore, modeling parameters can be difficult to characterize, since enabling an answer for each element of the facade can generate a mathematical problem almost impossible to optimize due to the number of possibilities [12-13]. Because of difficulties, parametric modeling is often considered under only aesthetic aspects with self-subjectivity content. This justifies the importance of establishing facade parametric modeling strategies (Figure 2). 

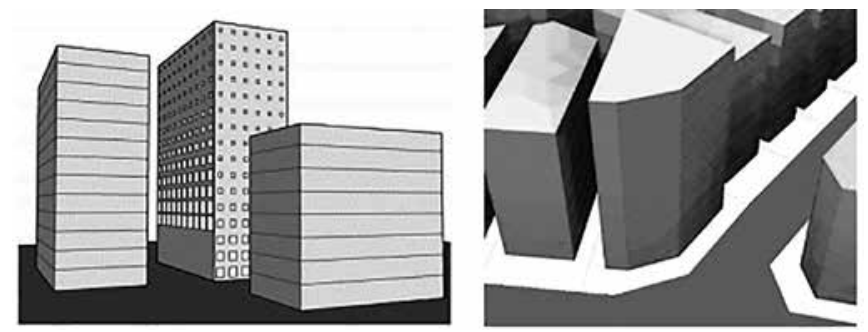

1
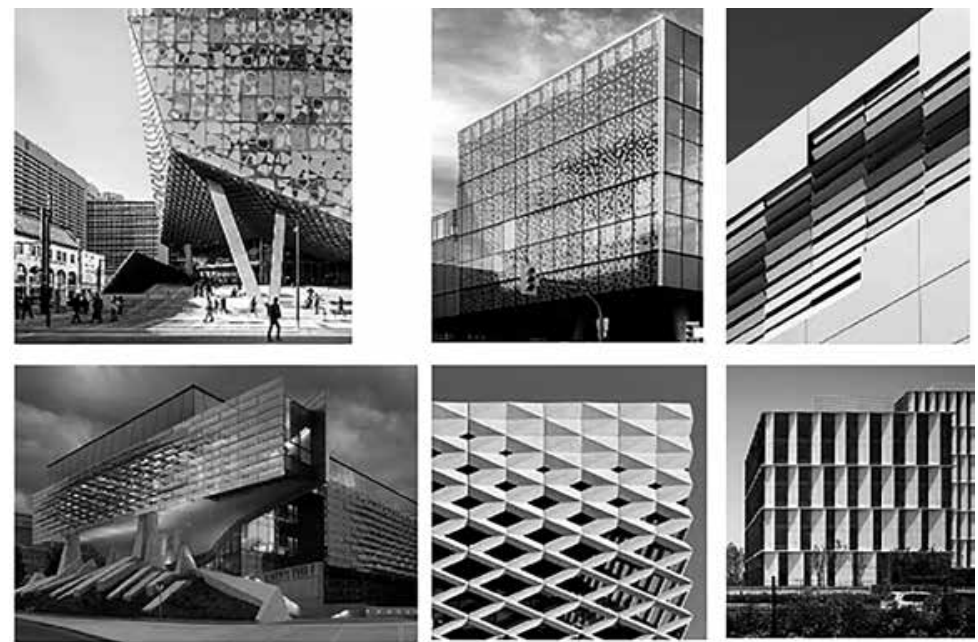

2

Figure 1. Left: the solution found to establish the minimum of natural lighting in indoor spaces [10]. Right: a radiation analysis and impact variations in different facades.

Figure 2. Parametric solutions in facades. Fritted glass and shading devices. Often the solutions are just for aesthetic aspects [14-19]. Figure 3. Study of complex facade elements with four levels of patterns [22]. 
Throughout the evolution of parametric modeling, different authors have theorized critical aspects of facade modeling. In common, is the understanding of a coordinate system with $\mathrm{U}, \mathrm{V}$ variables that characterizes the elements to distribute and modify in the facade system (20-26). Qian [22] presents a study on patterns where it demonstrates a system with four levels of variations: height, orientation of the opening, size and vertical projection. In addition to the number of units present on the facade, elements can have different levels of responses or combinatorial systems available (See Figure 3). Caetano and Leitão [21] proposed the classification of the parametric facade modeling process into four categories: Geometry, Distribution, Pattern, and Optimization and Rationalization.

Geometry is the category that defines the shape of the façade.

Distribution is the group of algorithms established for distributing elements on a facade's surface. The surface is generally subdivided into an array of elements on which the distribution will be made.

Pattern is the group of algorithms to create different data variations. Generally, the pattern is the result of the distribution of information in a two-dimensional domain. Finally,

Optimization and rationalization contain algorithms to analyze, optimize and rationalize the solution. They produce changes in the system according to designer interest [21].

In the parametric modeling process, the designer may have to initially make an extra effort to create the first associative model. On the other hand, due to this investment, changing or refining the model becomes easier compared to traditional modeling [27]. In this sense, the parametric process becomes promising when compared to traditional models that have more rework [3]. For associative or parametric modeling, the model created has a higher semantic value. This requires new modeling skills: in particular how to think associatively. The associative model has many advantages, and the designer can combine technical processes and go beyond associative modeling [27], however, not every design process is capable of generating associative digital models due to complexity. According to Oxman [28] the thought of parametric design as a strategic means is at the intersection of three fields of knowledge: in the algorithmic scheme of parametric design, in the cognitive scheme of the typology and topology of knowledge of architecture, and in the design of the digital process and the flow of information, guided by performance and in the generative design processes.

The performance-based design brings the measurable steps to the solution generation process [12]. With programming, initial time and effort may be apparently significant, but cognitive construction and the ability to regenerate the model within the project logic radically generates more possibilities when compared to traditional or non-algorithmic parametric modeling [27], [29]. The success of the integrated simulation model is related to the way the analyzed model is generated parametrically. It is essential to plan the logical steps, the flexibility of the 3D model, the selection of variable parameters and the design of system constraints [27], [29]. 
In parametric modeling, patterns can be guided or created by a third geometry: use of points, or attractor lines, by Boolean operations, images, etc. It can be also guided by performance, when the pattern is established by optimization, or by other primary data association with a given performance response. To exemplify, Figure $4 d$ shows the strategy presented by Giantini, et. al [14] where the manipulation of 10 attractor points is used. Figure $4 a$ shows the use of Boolean operations [23]. Figure $4 b$ represents a free modeling where each element has an individual behavior guided by an optimization process [24]. Figure $4 c$ shows the strategy of using vertical progressions to establish solutions for facades in all orientations in one optimization process [26]. Based on the restriction system, three modeling strategies for modeling patterns were found in the literature, also considering an optimization process:

1. Use of a fixed predefined pattern, that is, high constraint

2. Use of a free system guided by an optimization process with low restriction

3. Use of a mixed system, with a flexible pattern system with some restrictions

The first would be easier to optimize, since the pattern is fixed, but not necessarily the pattern has a relationship with the required performance. The second with low restriction, the pattern found is associated with the required performance, but the mathematical problem generated can be difficult to solve, since the number of possibilities can be significant. The third, the mixed solution, establishes a restriction strategy that allows flexible patterns that comply with a particular restriction system. Depending on desire, this combination can establish the most appropriate strategy for an optimization process where there is a desire to find a performance-based pattern.

Given the demand to incorporate variable patterns in building facades, it was perceived that the sounds emitted by birds respond to a problem similar in structure, as they allow thorough harmonic waves, for such pattern variations to emerge in response to their environment and activities. Hence the opportunity of exploring a possible strategy to create building facade patterns that incorporate harmonic waves in offering multi criteria performance-based solutions.

\section{Objective}

The goal of the paper is to present a novel strategy to establish patterns in facades and presents a bioinspired parametric mathematical model and its principles in order to simplify form-finding processes of complex solutions in responsive facades. 

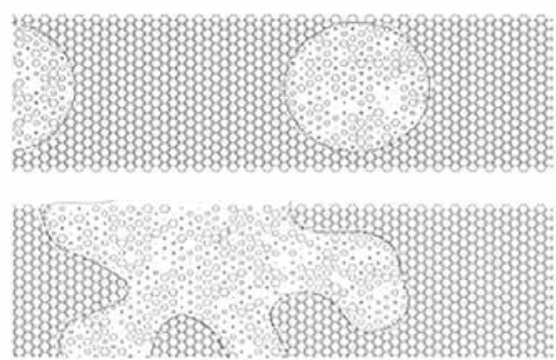

C

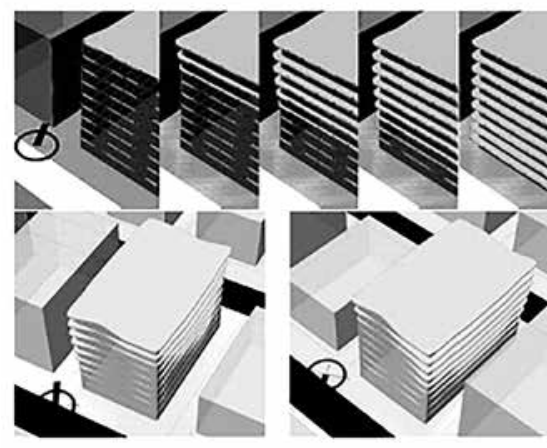

b

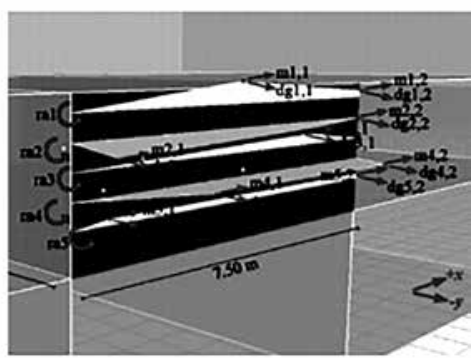

d

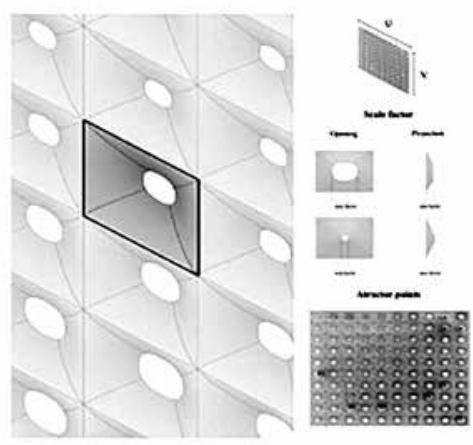

Figure 4. a) shows a fixed pattern solution with high restriction [23], b) shows a free system solution with patterns to be defined by an optimization process [24], c) and d) shows mixed pattern solutions that permit a diversity of patterns solutions with limited restriction systems [26],[14].

\section{Methodology}

This research explores a mixed methods approach in applied research through an experimental simulation formulation. The quantitative component structures the simulation through the bioinspired mathematical model established to generate parametric patterns for facades. The proposed model integrates critical multicriteria parameters for performance-based solutions, while exploring and optimizing the limits for viable solutions. The qualitative component of this research consists of architectural design process considerations, and bioinspiration focusing on its integration to the mathematical model. In this sense, natural patterns, and harmonic waves were key aspects in the development of this research. 
The practical steps of this research are subdivided into two parts: bio-inspiration and modeling. The first concerns the inspiration of nature. The second part demonstrates the development and application of the mathematical model. As for the considerations on the role of simulations in the architectural design process, four aspects were explored: generation of alternatives, accuracy, speed, and support for decision making.

\section{Bio-inspiration}

As mentioned, natural patterns, and harmonic waves were a key aspect of the bioinspiration for the mathematical model. In reviewing literature on harmonic waves, the Harmonograph emerged as an opportunity for the definition of bioinspired geometries. The harmonograph is a nature inspired machine that generates the sum results of two waves reproduced from a pendulum in a stationary table (See Figure 5). These pendular waves can be represented by a sine-based function. It is possible to obtain a diversity of solutions by changing the values of the waves for each pendulum, being them: the amplitude, frequency, and phase of the waves (See Figure 6 and 7) [30].

The logic of the harmonograph can be translated into a parametric equation that represents the $\mathrm{x}$ and $\mathrm{y}$ axis in a Cartesian system. Each function results in the generation of sine curves with variable frequency, amplitude, and phase values. Because of that, the variation of these curves allows the generation of a diversity of distinct patterns.

Inspired by the harmonograph's logic, it is possible to understand the facade system as a Cartesian system, but based on the $U$ and V axes, since it is usually part of a surface. Thus, a parametric equation can be established to manipulate the generation of patterns by crossing the results to the $\mathrm{U}$ and $\mathrm{V}$ axes generating a numerical matrix. The Wave inspiration can also be considered to have the potential to generate a diversity of harmonious patterns with changeable values. The mathematical model presented in this paper is based on these principles.

\section{Parametric Modeling}

Generally, the facade is divided into subunits located in a UV system established through the subdivision of an initial surface. These units represent the elements to be modified by the parametric action. The intention of this paper is to establish a strategy for the creation of patterns that can serve a diversity of geometric strategies and that allow flexible changes to an optimization process.

A critical aspect of the applicability in the architectural design process of this research was the choice of modeling tools and algorithmic programming interface. Therefore, it was required the use of a $3 \mathrm{D}$ modeler that integrated a visual programming plugin that also supported scripting languages. Thus, the mathematical model application in the parametric architecture model was developed using the plugin Grasshopper for Rhinoceros 3D, and Python script. 

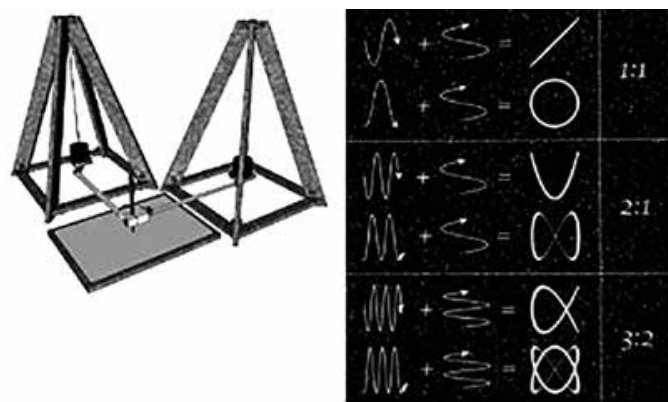

5

6

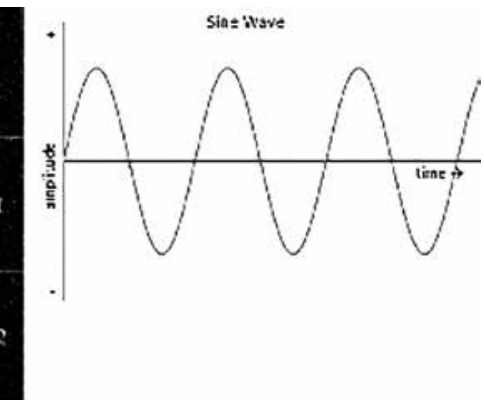

7

Figure 5. The Harmonograph. Figure 6. Some results in a pendulum Harmonograph. Figure 7. Characteristics and values of a sine wave.

\section{Results}

The mathematical model is based on a parametric equation composed of two functions. The equations are based on the sine function and were constructed in order to allow the variation of the different parameters of the waves. To establish the generation of a numerical matrix, the values of $U, V$ are obtained through a list of numbers with a domain that always varies between 0 and $x \varpi$. The list length must agree with the number of elements that make up the $\mathrm{U}$ and $\mathrm{V}$ axes in the facade subdivision. The functions of $\mathrm{U}$ and $\mathrm{V}$ are given by Equation 1 (See Equation 1).

Equation $1 \quad f(u, v)=\left(\mid \sin \left(\text { list }_{u} * \pi\right) \mid+t_{s}\right)^{2 k_{1}} *\left(\mid \sin \left(\text { list }_{v} * \pi\right) \mid+t_{s}\right)^{2 k_{2}}$

Where:

list ${ }_{u}$ is a list of numbers with the quantity of items according to $U$ axis. The domain should range from 0 to a number that represents the frequency on the $U$ axis.

list $_{\mathrm{v}}$ is a list of numbers with the quantity of items according to $\mathrm{V}$ axis. The domain should range from 0 to a number that represents the frequency on the $\mathrm{V}$ axis.

$\mathbf{t}_{\mathrm{s}}$ is a constant for the transition smoothness and is equal to 0,5 .

$\mathbf{k} \mathbf{1}$ is the Constant to modify the amplitude in the $\mathrm{U}$ axis.

$\mathrm{k} 2$ is the Constant to modify the amplitude in the $\mathrm{V}$ axis. 


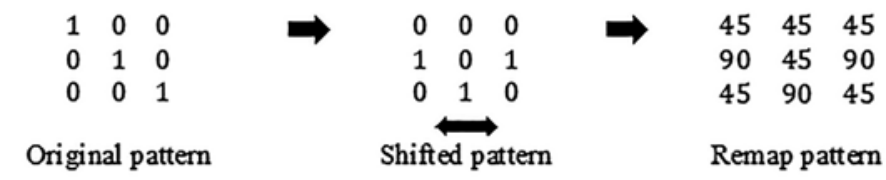

8
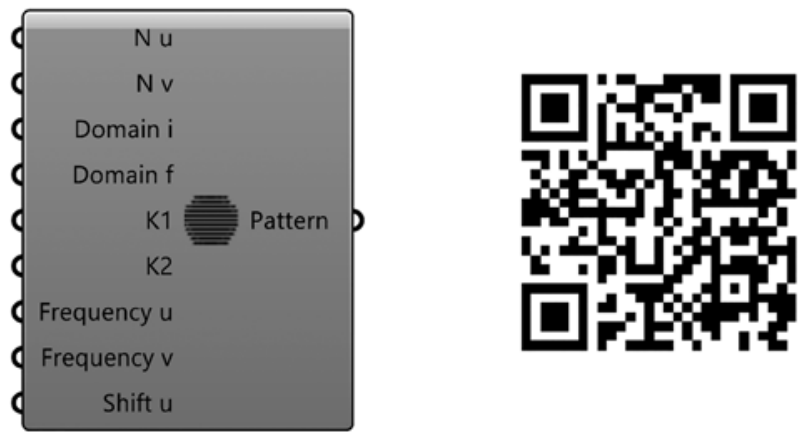

9

Figure 8. Additional steps included in the Grasshopper component.

Figure 9. The Grasshopper component and a QR code for download.

A Grasshopper component was created using Python script to produce and manipulate patterns (See Figure 9). The final output is a data tree-shaped array with a numeric pattern. In addition to calculating the matrix with the pattern according to Equation 1, two other actions are established by the component: the offset shift to move the solution along the $U$ axis, and the remapping of the quadratic domain in order to obtain numbers compatible with the action established for the parametric facade. The component has as inputs:

1. Number of units on the $\mathrm{U}$ axis (int)

2. Unit number on the $V$ axis (int)

3. Starting number of the final domain (float)

4. Final number of the final domain (float)

5. Number of constant K1 (float)

6. Number of constant K2 (float)

7. Frequency on the $U$ axis (float)

8. Frequency on axis $\mathrm{V}$ axis (float)

9. Number representing the shift offset on the $U$ axis (int) 

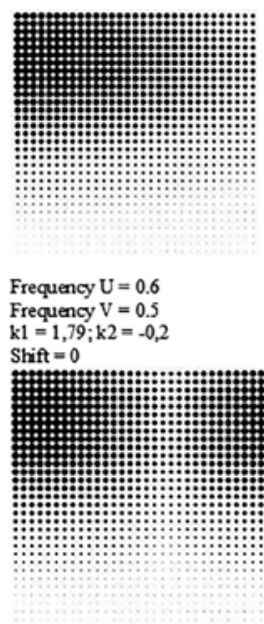

Frequency $\mathrm{U}=0.6$

Frequency $\mathrm{V}=1$

$\mathrm{k} 1=1,79 ; \mathrm{k} 2=-0,2$

Shift $=12$

10

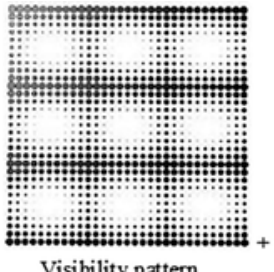

Visibility pattern
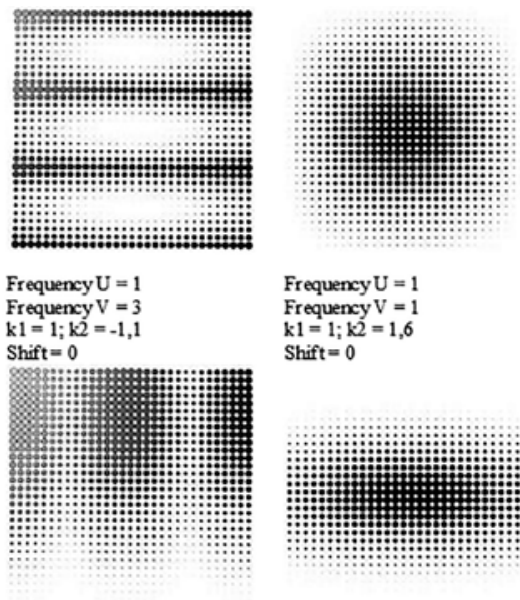

Frequency $\mathrm{U}=2$

Frequency $\mathrm{V}=0.6$

$\mathrm{k} 1=3 ; \mathrm{k} 2=0$

Shift $=\$$

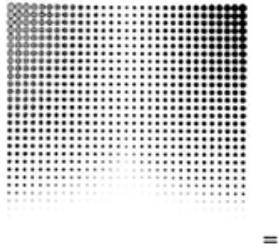

Shading pattern

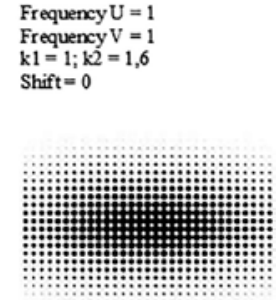

Frequency $\mathrm{U}=1$

Frequency $\mathrm{V}=1$

$\mathrm{k} 1=3 ; \mathrm{k} 2=0$

Shift $=0$

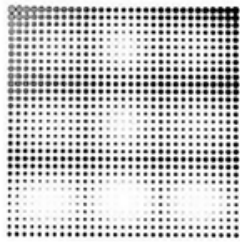

Final pattern
Figure 10. Patterns with the values used.

Figure 11. Sum of two patterns, establishing a new solution.

11

From the manipulation of inputs, it is possible to create a diversity of patterns and vary its positioning in the facade system. In addition to characterizing the pattern behavior, the data transition can be manipulated on both the $U$ and $V$ axes by creating variations of results even in a pattern with similar frequency and characteristics. The output is numerical, but to exemplify, Figure 10 shows results of different patterns in an array of circles with varying diameter through the pattern established by the manipulation of inputs.

Just as in harmonograph, it is possible to perform operations between different patterns by creating a combination that includes different levels of discussion with different characteristics. Figure 11 exemplifies a possibility. The first pattern would be to answer questions of visibility and privacy, and the second pattern would be to respond to the shading needs. The sum of the two brings a complex answer that integrates both discussions. 

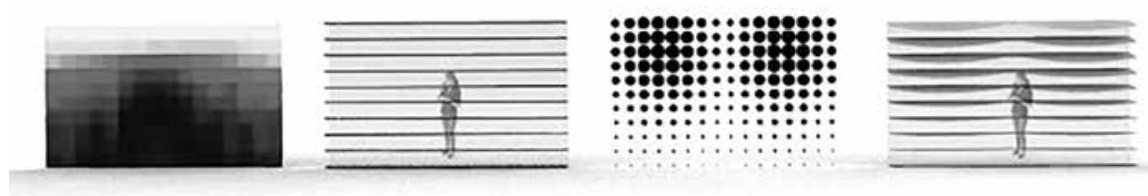

Figure 12. Use of the mathematical model to optimize a shading solution.

The possibility of modifying the results with numerical parameters allows good flexibility in optimization processes. Both the pattern and the transition characteristic of the appropriate results can be found through a generative process. Figure 12 exemplifies this possibility using as an example the protection of solar radiation in facades. The image on the left shows the sun exposure of the facade, which will receive a horizontal shading element with 10 fins. In this case, the shading device can be rotated parametrically to increase efficiency in regions with higher sun exposure. Both the pattern, and absolute values of rotation and transition can be found using a one-time optimization process.

\section{Conclusions}

The research proposed the development of a bioinspired mathematical model to support the facade design process while exploring multi criteria alternatives. The use of harmonic waves through the mathematical representation inspired by an harmonograph, allowed the construction algorithmic model to facilitate a performance-based design process, that effectively and efficiently generated design alternatives in the tested scenarios. The use of a 3D modeler combined visual programming and scripting reinforced the established ideations of algorithmic design as a powerful exploratory design approach for more complex designs. The results are discussed in the form of an experimental simulation formulation. Results indicate that the use of the proposed model allows for the exploration flexible responses within the specified parameters. The automated alternative generation in early facade design stages allows for its natural integration in the architectural design process. Given the nature of the performance driven algorithmic approach, it can support better decision making through information due to the flexible and simplified method. Such results are aligned with theorized potentials of this, much discussed, design method paradigm shift. Although it allows a diversity of patterns, the model does not necessarily replace other modeling strategies for parametric facades. Depending on the design demand, the alignment of the proposed method should be evaluated. The structure and algorithm results are illustrated through a sequence of examples of formal results.

Future research will consider prototyping of facade elements, and the integration of kinetic elements responsive to performance-based algorithms. Further developments also 
include explorations in optimization processes and Artificial Intelligence based models. Considering the objectives and declared limitations, we do believe that there is strong potential for applications in different design contexts and workflows.

\section{Acknowledgments}

The Foundation for Research and Innovation Support of the State of Santa Catarina (FAPESC) for the scholarship. The National Research and Development Council (CNPq), Process: 309394/2020-1 for financial support.

\section{References}

1. Kolarevic, B. (2003). Digital morphogenesis. Architecture in the digital age: Design and manufacturing, 12-28.

2. Kolarevic, B. (2003). Computing the performative in architecture.

3. Monedero, J. (2000). Parametric design: a review and some experiences. Automation in Construction, 9(4), 369-377.

4. Oxman, R. (2008). Performance-based design: current practices and research issues. International journal of architectural computing, 6(1), 1-17.

5. Oxman, N. (2010). Material-based design computation (Doctoral dissertation, Massachusetts Institute of Technology).

6. Queiroz, N. (2015). Artefatos geradores de microclima: biomimética, parametrização e prototipagem rápida na busca por soluções bioclimáticas para clima quente e úmido (Master's thesis, Universidade Federal de Pernambuco).

7. Tokuç, A., Özkaban, F. F., \& Çakır, Ö. A. (2018). Biomimetic Facade Applications for a More Sustainable Future. Interdisciplinary Expansions in Engineering and Design With the Power of Biomimicry, 77.

8. Al Horr, Y., Arif, M., Kaushik, A., Mazroei, A., Katafygiotou, M., \& Elsarrag, E. (2016). Occupant productivity and office indoor environment quality: A review of the literature. Building and environment, 105, 369-389.

9. Koolhaas, R., Westcott, J., \& Petermann, S. (2014). Elements of architecture. Venice: Marsilio.

10. Trubiano, F. (2013). Performance based envelopes: A theory of spatialized skins and the emergence of the integrated design professional. Buildings, 3(4), 689-712.

11. Reinhart, C. F., \& LoVerso, V. R. M. (2010). A rules of thumb-based design sequence for diffuse daylight. Lighting Research \& Technology, 42(1), 7-31.

12. Nguyen, A. T., Reiter, S., \& Rigo, P. (2014). A review on simulation-based optimization methods applied to building performance analysis. Applied Energy, 113, 1043-1058.

13. Kheiri, F. (2018). A review on optimization methods applied in energy-efficient building geometry and envelope design. Renewable and Sustainable Energy Reviews, 92, 897-920. 
14. Snøhetta and Zeidler Partnership. (2020). Fritted glass facade [jpg]. Architizer. https:// architizer.com/blog/inspiration/collections/fritted-glass-facade/\#media-1

15. Parkin Architects limited (2020). Winnipeg Women and Newborn Hospital (Goldray Glass). Archello. https://archello.com/story/81348/attachments/photos-videos/3

16. Takashi Tamaguchi \& Associates (2020). Parametric fragment. Archdaily. https:// www.archdaily.com/202570/parametric-fragment-takashi-yamaguchi-associates/ 5004fa0b28ba0d4e8d0012da-parametric-fragment-takashi-yamaguchi-associates-image ?next_project $=$ no

17. Halbe, Holand (2020). Melinda \& Bill Gates Hall [Jpg]. Archdaily. https://www.archdaily. com.br/br/763063/bill-and-melinda-gates-hall-morphosis-architects

18. ACME (2020). Eastland Town Center [jpg]. Parametric Architecture. https://parametric-architecture.com/eastland-town-center-by-acme/

19. Gahl, Christian (2020). Fabulous Group - Wulai Parking Structure [jpg]. Architizer. https: //architizer.com/blog/inspiration/collections/parametrically-designed-metal-facades/

20. Giantini, G., Negris de Souza, L., Turczyn, D., \& Celani, G. (2019). Environmental Ceramics-Merging the digital and the physical in the design of a performance-based facade system.

21. Caetano, I., \& Leitão, A. (2021). Mathematically Developing Building Facades: An Algorithmic Framework. In Formal Methods in Architecture (pp. 3-17). Springer, Cham.

22. Qian, Z. C.: Design Patterns: Augmenting Design Practice in Parametric CAD Systems. PhD thesis. School of Interactive Arts and Technology: Simon Fraser University. Burnaby, Canada (2009).

23. Caetano, I., \& Leitão, A. When the Geometry Informs the Algorithm.

18. Kirimtat, A., Krejcar, O., Ekici, B., \& Tasgetiren, M. F. (2019). Multi-objective energy and daylight optimization of amorphous shading devices in buildings. Solar Energy, $185,100-111$.

24. Caetano, I., \& Leitão, A. (2016). DrAFT: an algorithmic framework for facade design. In eCAADe 16: Complexity \& Simplicity, Proceedings of the 34th eCAADe Conference. eCAADe16 (pp. 465-474).

25. Queiroz, N., \& Pereira, F. (2021).A faster Multi-Criteria Optimization Model to parametric facades For Daylighting And Thermal performance. Encontro Nacional e Latino-Americano de Conforto no Ambiente Construído.

26. Aish, R. (2011). DesignScript: origins, explanation, illustration. In Computational design modelling (pp. 1-8). Springer, Berlin, Heidelberg.

27. Oxman, R. (2017). Thinking difference: Theories and models of parametric design thinking. Design studies, 52, 4-39.

28. Zhao, S., \& De Angelis, E. (2018). Performance-based generative architecture design: A review on design problem formulation and software utilization. Journal of Integrated Design and Process Science, 22(3), 55-76.

29. Papalambros, P. Y., \& Wilde, D. J. (2000). Principles of optimal design: modeling and computation. Cambridge university press.

30. Martineau, J. (2010). Quadrivium: The four classical liberal arts of number, geometry, music, \& cosmology. Bloomsbury. 
Resumen: La fachada es la piel que filtra y promueve la interacción entre el interior y el exterior del edificio. Durante su proceso de concepción, se debe comprender los patrones ambientales, observar el clima incidente y proponer soluciones que consideren el uso del edificio y aprovechen las oportunidades del clima, filtrando ventajas y desventajas. Las fachadas están compuestas por elementos opacos y transparentes, cerrados y abiertos, y las aberturas son los elementos que promueven la mayor conexión entre los ambientes externos e internos. Las exploraciones de diseño recientes consideran el modelado paramétrico y la fabricación digital como estrategias para establecer y fabricar soluciones de fachada complejas. Sin embargo, estas soluciones a menudo ignoran su función de filtrado selectivo, por lo que las soluciones se establecen con frecuencia a través de requisitos estéticos. La complejidad de modelar la solución de revestimiento del edificio asociada con los requisitos de rendimiento dificulta un enfoque compatible con los requisitos bioclimatológicos, de eficiencia, y biomiméticos, ya que aumenta la complejidad del problema matemático para los procesos de optimización asociados con las características ambientales. Este artículo presenta un modelo matemático inspirado en la naturaleza y sus principios para simplificar los procesos de búsqueda de formas de soluciones complejas en fachadas receptivas. El resultado presenta un algoritmo flexible simplificado capaz de generar patrones para cualquier tipo de sombreado y/o solución de apertura, con el fin de facilitar los procesos de modelado y optimización de las soluciones de fachada. El algoritmo generado se aplica mediante el script Python, Grasshopper y Rhinoceros 3D.

Palabras clave: Fachada - Modelado paramétrico - Bio-inspiración - Algoritmo - Pattern - Diseño de fachada - Piel de edificio - Diseño responsive - Grasshopper - Python

Abstract: A fachada é a pele que filtra e promove a interação entre o interior e o exterior do edifício. Durante o seu processo de concepção, deve-se entender os padrões ambientais, observar o clima incidente e propor soluções que considerem o uso da edificação e aproveitem as oportunidades do clima, filtrando vantagens e desvantagens. As fachadas são compostas por elementos opacos e transparentes, fechados e abertos, e as aberturas são os elementos que promovem a maior ligação entre os ambientes externo e interno. Explorações de design recentes consideram a modelagem paramétrica e a fabricação digital como estratégias para estabelecer e fabricar soluções de fachada complexas. No entanto, essas soluções muitas vezes desconsideram sua função de filtragem seletiva, portanto, as soluções são estabelecidas frequentemente por meio de requisitos estéticos. A complexidade da modelagem da solução de pele do edifício associada aos requisitos de desempenho dificulta uma abordagem compatível com a bioclimatologia, eficiência e requisitos biomiméticos, pois aumenta a complexidade do problema matemático para processos de otimização associados às características ambientais. Este artigo apresenta um modelo matemático inspirado na natureza e seus princípios para simplificar os processos de descoberta de formas de soluções complexas em fachadas responsivas. O resultado apresenta um algoritmo simplificado e flexível capaz de gerar padrões para qualquer tipo de dispositivo de sombreamento e / ou solução de abertura, a fim de facilitar os processos de 
modelagem e otimização de soluções de fachada. O algoritmo gerado é aplicado usando script Python, Grasshopper e Rhinoceros 3D.

Palavras-chave: Façade - Modelagem paramétrica - Bioinspiração - Algoritmo - Padrão Projeto de fachada - Construção de skin - Design responsivo - Grasshopper - Python 